\title{
Prevalence and Absolute Quantification of NDM-1: A $\beta$-Lactam Resistance Gene in Water Compartment of Lakes Surrounding Hyderabad, India
}

\author{
Rajeev Ranjan ${ }^{a}$, Shashidhar Thatikonda ${ }^{b, *}$ \\ ${ }^{a}$ Department of Civil Engineering, Indian Institute of Technology Hyderabad, India \\ ${ }^{b}$ Department of Civil Engineering, Indian Institute of Technology Hyderabad, India
}

\begin{abstract}
New Delhi Metallo-beta-lactamase-1 (NDM-1) is considered an emerging environmental contaminant, which causes severe hazards for public health. Screening and absolute quantification of the NDM-1 gene in 17 water samples collected from a different sampling location surrounding Hyderabad, India, was performed using a real-time quantitative polymerase chain reaction (qPCR) in the study. Absolute quantification achieved by running the isolated DNA (Deoxy-ribonucleic acid) samples from different water bodies in triplicate with the known standards of the NDM-1 and results reported as gene copy number/ng(nanogram) of template DNA. All collected samples had shown a positive signal for the NDM-1 during qPCR analysis. Among the tested samples, the highest gene copy number/ng of template DNA was observed in the Mir Alam tank (985.74), which may be due to the combined discharge of domestic sewage and industrial effluents from surrounding areas and industries. Shapiro-Wilk test was conducted to correlate the distribution of NDM-1 gene copies among sampling locations. The variation observed in the distribution of gene copies number of NDM-1 gene among sampling locations is big enough to be statistically significant. $(\alpha=0.05, p$-value $=0.00056)$. Further, a hierarchical clustering analysis was performed to group sampling locations in clusters, and results were presented in the form of a dendrogram.
\end{abstract}

Keywords: Antibiotic Resistance, NDM-1, Lake Water, qPCR, Hierarchical Clustering

\section{Introduction}

The drastic prevalence of the antibacterial resistance gene (ARG) has become a daunting concern for public health due to its potential harm [1]. The ARGs have mainly induced health benefits from discovering antibiotics to combat pathogens and have made them a reliable therapeutic medicine for the public [2]. Despite their therapeutic benefits, the large consumption of antibiotics in human and veterinary treatment accelerated antimicrobial resistance (AMR) growth as an emerging global contaminant [3]. The primary attribute involves AMR encoding functions, such as antibiotic efflux, the degradation of antibiotics, or chemical modification of the cell wall, making it no longer susceptible to pathogenic strains [4]. Multiple drug-resistant (MDR) bacteria are formed primarily from hospital-based areas and other environments like water bodies, where chances of higher amounts of antibiotics are utilized or excessively disposed of [5]. It collectively resulted in an elevated MDR bacteria occurrence within the environment, resulting in more anthropogenic pollution than strains that exhibit sole resistance [6].

\footnotetext{
* Corresponding author.

E-mail address: ce16resch01004@iith.ac.in

Manuscript History:

Received 6 March, 2021, Revised 22 April, 2021, Accepted 23 April, 2021, Published 30 April, 2021
}

e-ISSN: 2289-7771 
Water matrices act as the primary breeding ground in the occurrence of antibiotics resistance bacteria (ARB) and ARGs [7, 8]. When these bacteria incorporate species in the genera Acinetobacter, Aeromonas, Pseudomonas, Stenotrophomonas, their probabilities of existence in these matrices are high. They get introduced to the residues of the antibiotics in the environment (particularly in the water matrices), which may lead to the development of a high level of resistance that further makes these bacteria more resistant against several classes of antibiotics [9]. ARGs are transmissible and generally capable of being transferred among bacteria [10]. Therefore, direct monitoring provides information about the rapid increase of antibiotic resistance in a system [11]. The account of antimicrobial resistance elements in bacteria at the heritable level plays a severe role in understanding and possibly governing resistance [12]. One key concern indicated from earlier studies is that a microbial community DNA demonstrated that resistance genes, conferring resistance over a more extensive array of antibiotics, are abundant in water bodies like the river and lake sediments contaminated by effluent [13].

Recently, India has been combating against the rise in ARG, especially with the emergence of NDM-1 carrying superbug [14]. The country has reported supplying $20 \%$ of global generic drugs, an anti-infective account to a substantial share produced in bulk from significant drug manufacturing plants stationed in Hyderabad, Telangana [15]. These plants have been disposing of waste into the surrounding environment without giving a proper degree of treatment, causing contamination of lakes and lakes $[16,17]$. A large number of antibiotics, combined with agricultural runoffs and human waste in water bodies and sewage treatment plants, contribute to MDR bacteria's proliferation. Therefore, India has emerged as an epicenter of antibiotics resistance, with extreme clinical concerns. The existence of the NDM-1 and carbapenemases in water and sediment samples cause a severe threat to citizens' dependent on public water supply and sanitation amenities [18].

NDM-1 inactivates the important beta-lactam group containing antibiotics by cleaving the blactam rings. In several bacterial species, such as Klebsiella sp., Shigella boydii, Escherichia coli, and Vibrio cholera, the NDM-1 presence reported that they could gene transfer horizontally [19]. Bacterial species carrying NDM-1 genes are reported globally around different countries [19, 20]. At least 14 other antibiotic resistance variants of plasmids possess the gene for the NDM-1 that can transmit this resistance to several different bacterial species, resulting in multidrug-resistant strains [21]. The earlier study revealed the wide dissemination of the NDM-1 in India and its subcontinent [21, 22]. The foremost positive isolate of the NDM-1 was identified from a Swedish citizen who came in contact with infection caused by Klebsiella pneumoniae in late 2007 while residing in India. The frequent introduction of NDM-1-positive bacteria to Asia, Europe, Canada, the USA, and Australia observed from the Indian subcontinent since 2008, which repeatedly facilitated through transmissions of patients, besides some direct transfer in Europe [23]. World Health Organization (WHO) has advised all the nations to enact strategies to control the infection that can stop the proliferation of NDM-1 producing bacteria [19]. A precise and quick screening and quantification of NDM-1 possessing bacteria are essential and significant for both environmentalists and health care providers. In spreading the NDM-1, the environment is expected to play a vital role in disseminating antibiotic resistance between environmental and pathogenic bacteria. The proximate urban environment has still been observed as prospective hotspots for antibiotic resistance distribution and growth [18]. The usual concern of inadequate sanitation systems in India's diverse parts [24] led us to investigate the abundance of the NDM-1 gene in the water bodies surrounding Hyderabad, India. The objective of the study to evaluate the environmental prevalence and dissemination of the NDM-1 gene in water samples collected from lakes, rivers, and water treatment plants (WTP) surrounding Hyderabad using a real-time qPCR. 


\section{Material and Methods}

\subsection{Sample location and collection}

The sampling area of Hyderabad city and surroundings extend from $17^{\circ} 23^{\prime} 13.7040^{\prime \prime} \mathrm{N}$ and $78^{\circ}$ $29^{\prime} 30.0624^{\prime \prime}$ E. It encounters a base temperature of $11.60^{\circ} \mathrm{C}$ and a limit of $40.50^{\circ} \mathrm{C}$ with an average yearly precipitation of $73.55 \mathrm{~cm}$. Hyderabad inhabits 625 square kilometers along the Musi River banks, situated on the Deccan Plateau in the northern piece of South India at an average elevation of 542 meters. The water samples collected using a $100 \mathrm{ml}$ sterile sampling bottle in the first week of January 2019 from seventeen geographically distinct lakes, rivers, and water treatment plants (WTP) surrounding Hyderabad Region, Telangana (Fig.1). Water samples after collection were carried to the laboratory in an ice container and kept at $4{ }^{\circ} \mathrm{C}$ for the isolation of DNA.

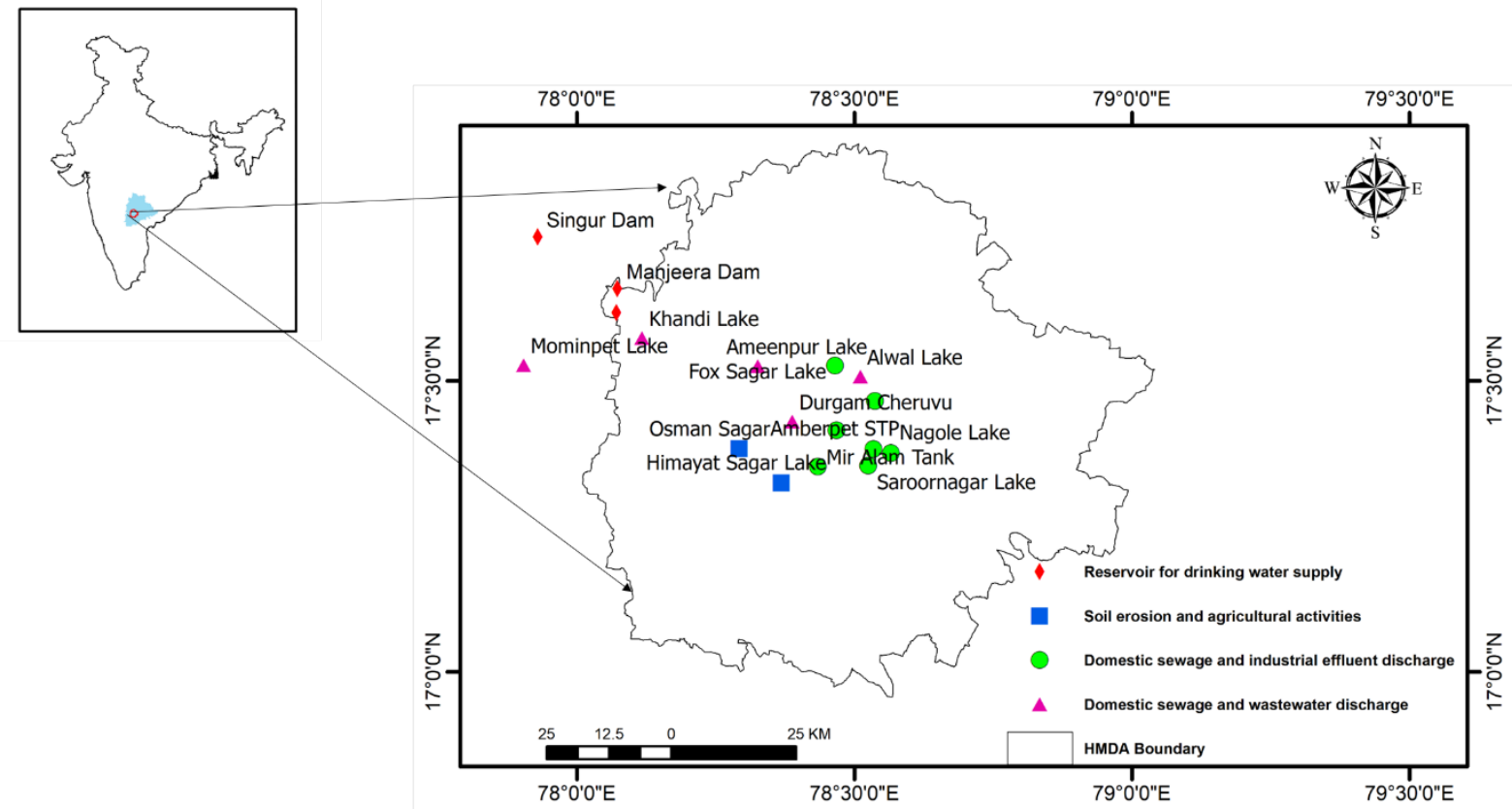

Figure 1. Sampling locations surrounding Hyderabad.

\subsection{Isolation and purification of DNA from water samples}

Subsequent isolation of DNA from water samples achieved within $48 \mathrm{hrs}$ of sample collection using DNA/RNA isolation Kit - NucleoMag by Macherey-Nagel GmbH \& Co. KG., and stored at $20^{\circ} \mathrm{C}$ for $\mathrm{qPCR}$ assay. The study employed Eon ${ }^{\mathrm{TM}}$ Microplate Spectrophotometer (BioTek Instruments, Inc., USA) to check the purity and concentration of extracted DNA. Usually, the ratio of $\mathrm{A}_{260} / \mathrm{A}_{280}$ values ranging between $1.8-2.0$ reflects the purity of extracted DNA.

\subsection{Primer Design}

The primer used in the study was designed using reference nucleotide sequences for NDM-1 in GenBank under accession number FN396876.1 (Klebsiella pneumoniae plasmid pKpANDM-1 sequence carrying new Metallo-beta-lactamase gene NDM-1, isolate KP-05-506). Using PrimerBLAST, a specific primer pair was designed on the target sequence and then commercially synthesized by Eurofins Genomics India Pvt Ltd. The designed primer sequence consists of 
forwarding primer 5'- GTACTGGCGTAACCCTTCACA $-3^{\prime}$ and the reverse primer 5'CATTCATGGCGGGCAGGATAA -3' for amplification of a sequence of 121 base pair for screening and quantification of the NDM-1 gene. The primer-BLAST analysis was used to check the specificity of the designed primer (http://www.ncbi.nlm.nih.gov). BLASTN analysis of the designed primers for the real-time qPCR assay revealed a 100\% homogeneity with the NDM-1-encoding gene only.

\subsection{Real-time qPCR assay}

Assays involving a real-time qPCR optimization accomplished using a real-time qPCR system CFX-96, Bio-rad Laboratories (India) Private Limited using SYBR green chemistry. Protocols followed as per TB Green ${ }^{\mathrm{TM}}$ Premix Ex Taq ${ }^{\mathrm{TM}}$ (Tli RNaseH Plus) purchased from DSS Takara Bio India Private Ltd. Undiluted $1 \mu \mathrm{L}$ (microliter) of final DNA extracts used in triplicate during the experiment. All reactions carried out for analysis comprising a reaction mixture prepared by adding 4.2 $\mu \mathrm{L}$ of template DNA, $21 \mu \mathrm{L}$ of Sybrgreen Master mix, $0.8 \mu \mathrm{L}$ of $10 \mu \mathrm{M}$ Forward primer, $0.8 \mu \mathrm{L}$ of $10 \mu \mathrm{M}$ (micromolar) Reverse primer, and $15.1 \mu \mathrm{L}$ of PCR Grade Water. The plate setup for each reaction comprises of an unknown sample in triplicate, a negative control (NC), and no-template control (NTC) in duplicate and five known standards of NDM-1 [100 pg (picogram) $/ \mu \mathrm{L}, 10 \mathrm{pg} / \mu \mathrm{L}, 1$ $\mathrm{pg} / \mu \mathrm{L}, 100 \mathrm{fg}$ (femtogram) $/ \mu \mathrm{L}$ and $10 \mathrm{fg} / \mu \mathrm{L}]$. The optimal cycling protocol consists of one initial cycle of denaturation and polymerase activation step at $95^{\circ} \mathrm{C}$ for $30 \mathrm{sec}$., followed by 40 cycles of denaturation at $95^{\circ} \mathrm{C}$ for 5 secs, 40 cycles of annealing at $60^{\circ} \mathrm{C}$ for 30 secs, extension at $72^{\circ} \mathrm{C}$ for 30 secs, 1 cycle of melt curve from $65-95^{\circ} \mathrm{C}, 0.2^{\circ} \mathrm{C}$ increments at $10 \mathrm{secs} / \mathrm{step}$. The standards of the NDM-1 synthesized using known quantities of cloned target genes provided by Bioartis Life Sciences Private Limited, Hyderabad.

\subsection{Hierarchical clustering and Statistical analyses}

Hierarchical clustering was conducted using the ward's linkage method followed by Euclidean distance measurements to group sampling locations in clusters based on their similarity. Shapiro-Wilk test was performed using R software to correlate the NDM-1 gene copies distribution among sampling locations [25].

\section{Results}

\subsection{Amplification and quantification of the NDM-I gene}

The system evaluated several lakes and river water isolates with possible NDM-1 bearing strains from 17 different geographic origins and further quantified using a real-time qPCR system CFX-96, Bio-Rad India Pvt. Limited. Amplification and quantification were performed by running the unknown sample in triplicate with the known standards of the NDM-1 and results reported in gene copy number/ng of template DNA. Data analysis performed using CFX maestro software 1.1 (Version 4.1.2433.1219) provided along with the thermal cycler and results summarized in Table 1. In the study, the B-lactamase resistance gene NDM-1 was detected in all the samples (Table 1). Concentrations were sufficiently high and observed positive for all the samples collected. All test samples positive for the NDM-1 gene exhibited Cq values between 21 to 34. The cut-off cycle threshold value was determined as 35 for positive amplification. The ideal number of amplification cycles fixed as 40 for the qPCR assay. The signal obtained above 35 cycles was considered nonspecific for any test sample. Repeated runs in triplicates with the known standards of the NDM-1 gene demonstrated a significant coefficient of correlation $\left(\mathrm{r}^{2}\right)$ value between 0.693 to 1, and PCR reaction efficiency varies from 90 to $110 \%$. The standard curve method was used to determine the gene copies of the NDM-1gene per nanogram of template DNA in test samples during analysis. 
Table 1. Absolute quantification of NDM-1 in DNA isolated from water samples

\begin{tabular}{|c|c|c|c|c|c|}
\hline S.No. & $\begin{array}{c}\text { Sampling } \\
\text { locations }\end{array}$ & $\begin{array}{c}\text { Quantification } \\
\text { cycle (Cq) }\end{array}$ & $\begin{array}{c}\text { Coefficient of } \\
\text { determination } \\
\left(\mathbf{r}^{2}\right)\end{array}$ & $\begin{array}{c}\text { Efficiency } \\
\mathbf{( \% )}\end{array}$ & $\begin{array}{c}\text { Gene copy } \\
\text { number/ng of } \\
\text { template DNA }\end{array}$ \\
\hline W1 & Alwal lake & $32.03 \pm 0.374$ & 0.893 & 92.6 & 40.81 \\
\hline W2 & Amberpet STP & $31.42 \pm 0.333$ & 0.997 & 96.7 & 3.00 \\
\hline W3 & Ameenpur lake & $32.30 \pm 0.004$ & 0.956 & 103.4 & 3.47 \\
\hline W4 & Durgamcheru lake & $28.70 \pm 0.065$ & 0.969 & 101.6 & 146.50 \\
\hline W5 & Fox Sagar lake & $27.73 \pm 0.413$ & 0.942 & 104 & 202.92 \\
\hline W6 & Himayat Sagar lake & $23.85 \pm 0.320$ & 0.997 & 90 & 607.22 \\
\hline W7 & Hussain Sagar lake & $28.68 \pm 0.145$ & 0.924 & 91.7 & 37.55 \\
\hline W8 & Kandi lake & $25.78 \pm 0.493$ & 0.918 & 90.5 & 225.16 \\
\hline W9 & Manjeera dam & $26.14 \pm 0.054$ & 0.863 & 94.9 & 417.37 \\
\hline W10 & Manjeera WTP & $33.90 \pm 0.216$ & 0.966 & 103.4 & 3.58 \\
\hline W11 & Mir Alam tank lake & $21.61 \pm 0.328$ & 0.995 & 90.6 & 985.74 \\
\hline W12 & Mominpet lake & $27.32 \pm 0.360$ & 0.995 & 102.1 & 46.37 \\
\hline W13 & Nagole lake & $29.20 \pm 0.480$ & 0.693 & 106.7 & 204.88 \\
\hline W14 & Osman Sagar lake & $32.12 \pm 0.467$ & 0.905 & 109.9 & 3.58 \\
\hline W15 & Safilguda lake & $26.09 \pm 0.195$ & 0.954 & 103.3 & 221.19 \\
\hline W16 & Saroor Sagar lake & $27.23 \pm 0.239$ & 0.915 & 90.1 & 116.27 \\
\hline W17 & Singur dam & $26.93 \pm 0.043$ & 0.959 & 102.2 & 239.92 \\
\hline
\end{tabular}

\subsection{Hierarchical Clustering analysis}

The analysis was performed to categorize samples based on their pollution sources. It facilitates tracking the NDM-1 gene pollution from different sources that act as a necessary element in eliciting the NDM-1 determined from qPCR data. A cluster analysis divided the data into four main clusters, involving Ward's linkage method followed by Euclidean distance measurements. The clusters formed in the dendrogram using cluster analysis illustrated in Fig.2, by employing seventeen typical peaks considered clustering variable, referring lake sediment samples (W1-W17) from different geographically distinct water bodies. The dendrogram implemented a single-linkage rescaled distance cluster. There were four clusters grouped as A, B, C, and D involving seventeen common constituents. Based on pollution sources and observed data, the following observations were attained from the dendrogram (Fig.2). The rescaled distance cluster performed based on pollution sources impacting NDM-1 in the dendrogram identified that the water samples of Cluster A comprised water bodies polluted due to combined discharge of domestic sewage and industrial effluents. In cluster A, Hussain Sagar lake is regarded as the largest lake in the vicinity. A considerable increase in contamination level was observed for past decades, leading to the accumulation of pollutants in lake sediments that cause a potential threat of contributing pollution to the surrounding groundwater.

Similarly, the Durgamcheru lake otherwise referred to as a secret lake, has already been recorded with a low biological oxygen demand due to effluent discharge from commercial complexes and residential buildings. Cluster B is comprised of water bodies polluted due to domestic sewage and industrial effluents. From the observed dendrogram, there are two sub-cluster with Manjeera dam (W9), Safilguda lake (W15), and Kandi lake (W8) clustered together; followed by Momnipet (W12), Saroor Sagar (W16), Singur Dam (W17), and Fox Sagar (W5), respectively were grouped firmly. Cluster A and B were noted to be closest in terms of their clustering distance observed. It is attributed as a result of similar pollution sources. 
Cluster $\mathrm{C}$ is comprised of water bodies that are polluted due to domestic sewage discharge and agricultural runoffs. Mir Alam Tank (W6) and Himayat Sagar (W11) clustered together. Cluster D comprised of sub-clusters Alwal Lake (W1), Osman Sagar (W14), Ameenpur Lake (W3), Amberpet STP (W2), and Manjeera dam (W10), which polluted due to multiple pollutants such as domestic sewage, industrial effluents, wastewater discharge, and agricultural runoffs. The clustering patterns appeared consistent from clustering analysis between water bodies expressed in the dendrogram.

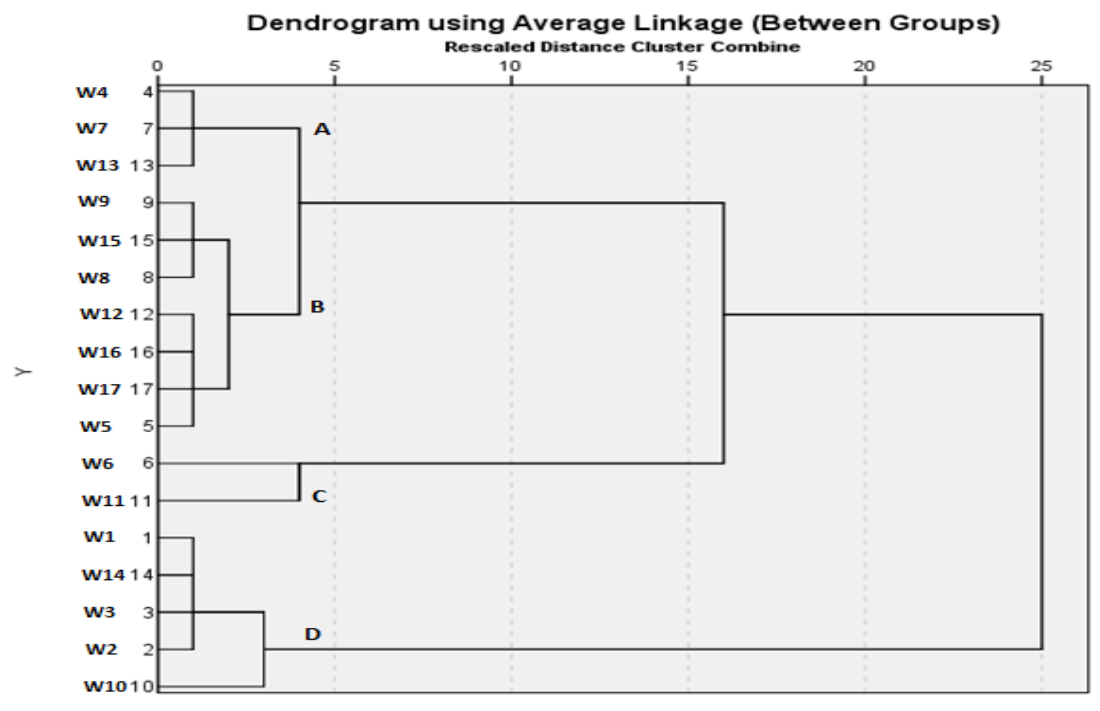

Figure 2. Dendrogram obtained by cluster analysis

\subsection{Statistical analyses}

Shapiro-Wilk test was performed using R software to correlate NDM-1 gene copies distribution among sampling locations. The variation observed in the distribution of gene copies number of NDM1 gene among sampling locations is big enough to be statistically significant. $(\alpha=0.05$, p-value $=$ 0.00056 ). Since $p$-value $<\alpha$, it is assumed that the gene copies number is not normally distributed (Fig. $3)$.

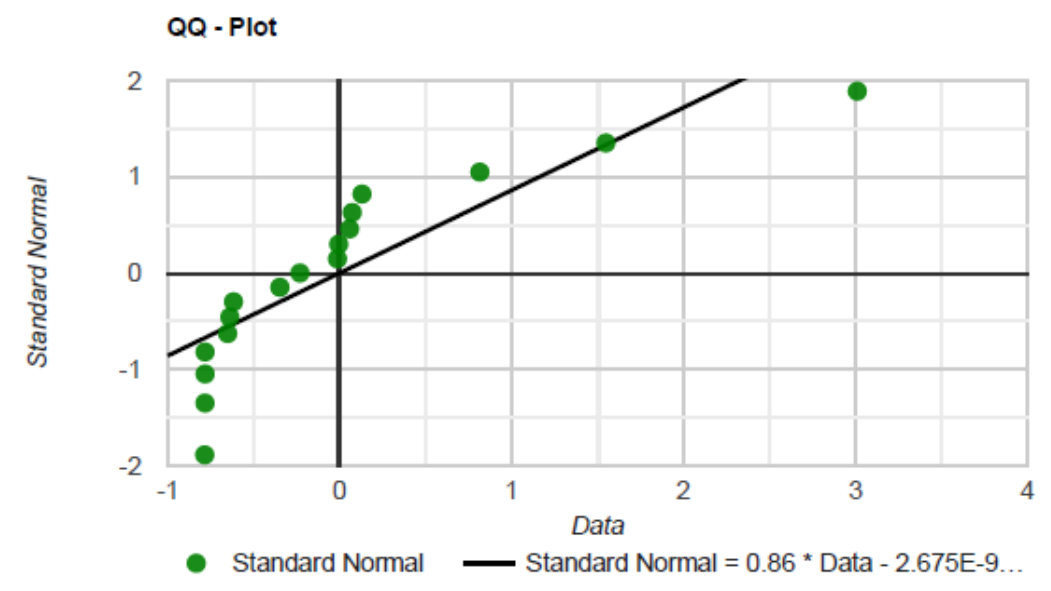

Figure 3. Quantile-Quantile (Q-Q) plot showing the distribution of the NDM-1 gene copies among sampling locations 


\section{Discussion}

Among the tested samples, the NDM-1 gene was detected in water samples from all 17 sampling locations. The highest value of the NDM-1 gene copies number was observed in the Mir Alam tank (985.74), followed by the Himayat Sagar lake (607.22) and the Manjeera dam (417.37). These water bodies were polluted due to the combined discharge of domestic sewage and industrial effluents. The occurrence of the highest gene copies number/ng of template DNA in the Mir Alam tank may be due to the collective discharge of domestic sewage and industrial effluents from its surrounding areas and industries [15]. A significant variation in the distribution of the gene copies number of NDM-1 gene was observed among sampling locations. A small to moderate variation in abundance of NDM-1 in these water bodies depends upon various parameters such as season and conductivity, microbial diversity, different types of antibiotics exposed, $\mathrm{pH}, \mathrm{TSS}$, metals [26]. The study provided firm evidence and could be regarded as an authentic report that shows the presence of the NDM-I genes in these water bodies that serve the purpose of drinking water supply for urban areas (Himayat Sagar, Manjeera dam, and Osman Sagar). As water bodies are more prone to disseminating antimicrobial agents in industrial effluents and untreated wastewater/ sewage discharges, Hyderabad was reported as a 'growing hub' for major pharmaceutical manufacturers. Several established manufacturing plants generating and dumping industrial effluents in enormous quantities into nearby water bodies every day. There are numerous supporting reports showing AMR or otherwise MDR contamination from drinking water samples or industrial effluents from Hyderabad's water bodies.

Studies showed that ARGs are the primary triggering factor for disseminating MDR bacteria in surrounding environs. This particular study aimed to unravel the overall prevalence of NDM- 1 gene from water samples derived from 17 geographically distinct water bodies surrounds Hyderabad city. The reason for screening the NDM-I gene in particular for the study is primarily due to their rapid transferring capability followed by the increased occurrence of the NDM-1 gene in almost the majority of India's regions, thereby making them a potential threat on a national and even a global scale $[27,28,29]$. Consequently, the frequent indiscriminate use of antibiotics for human health care, their application in animal husbandry and aquaculture resulted in mounting resistance over such agents globally $[30,31,32]$. This transfer in resistance factors within bacterial species followed further dissemination across the entire community via mobile genetic elements (MEGs) such as plasmids, transposons, and integrons were extensively studied. The resistance genes existing within the microbes could lead to a broader threat to the human community while coming across contaminated water, foods, animal husbandry, and the aquatic environment [33].

Instances showcasing the emergence of a novel class of NDM-1 reported in the Indian subcontinent in 2008, and ever since their initial elucidation, there has growing evidence of its prevalence studied worldwide [34, 35, 36, 37]. Reports from China exhibited hospital sewage samples that tested positive for NDM-1, signifying them to serve as a reservoir to NDM-1[38]. In contrast, considering the overall detection of the NDM-1 gene observed among various Gram-negative bacterial genera indicating that the gene could spread at a much greater rate. Hospital wastewater emerged as the primary source of NDM-1 producing microbes. Studies indicate the NDM-I prevalence in such an environment representing their pathogenicity to be superior in such antibioticenriched conditions $[38,39]$.

However, there are reports to further add to the investigation concerning the NDM-I prevalence in large water bodies. A study conducted by [40] in Vietnam described bacterial species producing NDM-1 from tested rivers and lake samples, thus representing their broader distribution in the aquatic environment. The presence of numerous dissimilar Gram-negative species in public tap water and sewage in New Delhi has shown the existence of the NDM-1, signifying its prevalence in the Indian environment. Most NDM-1 carrying isolates are enterobacterial species, though it has been found from Acinetobacter species and Pseudomonas aeruginosa. The investigations performed by [15] further undermine the very fact that there is a rapid propagation of beta-lactamase and Carbapenems 
producing bacteria from 24 different sample locations. The present investigations comprising of water samples derived from 17 different geographically distinct water bodies involving river/ lake and reservoir water samples were subjected to screening and quantifying the NDM-1 using a real-time qPCR. This study is carried out with much more significant concern about their overall prevalence on water bodies utilized for domestic and industrial purposes. Fig. 4 provides a graphical illustration representation of the distribution of the gene copy number/ng of template DNA among sampling locations.

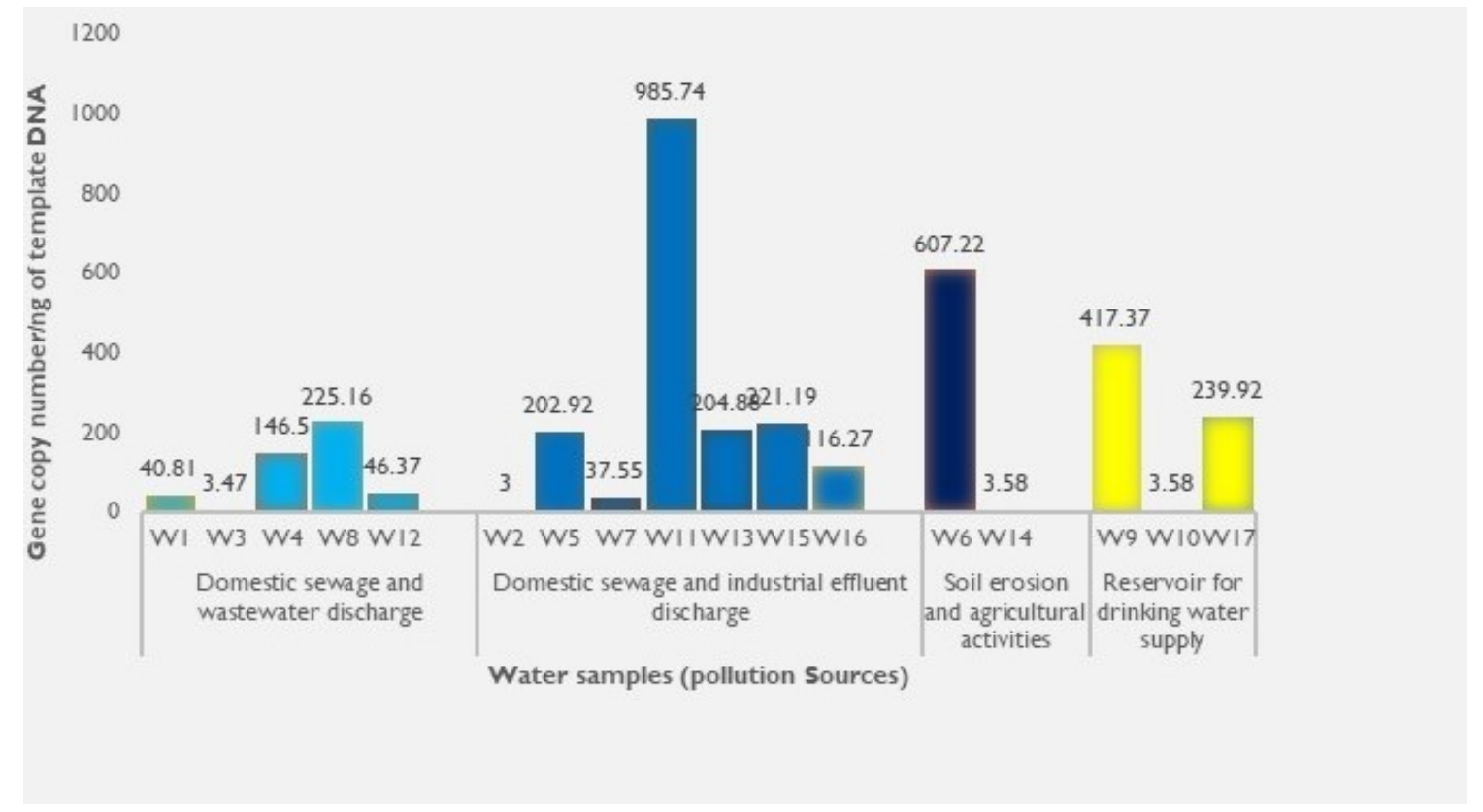

Figure 4. Gene copy number distribution among water samples

This public health hazard cannot be left unhandled as these existing organisms carrying the NDM-1 gene serve as a vector as they could facilitate in transferring to the other bacterial community quickly [29]. Besides, one prominent concern is its ability to exhibit multiple resistance as reports indicated NDM-1 isolates were observed with limitations for treating its patients [41]. The study conducted by [29] revealed the co-existence of CTX-M and SHV genes among isolates tested with positive NDM-1. It could be ascribed that these NDM-1 encoded bacteria tend to express other unrelated genes, such as genes encoding for enzymes like aminoglycosides, macrolides, AmpC, sulfamethoxazole cephalosporinases, fluoroquinolones, and carbapenemases [42]. The overall observation achieved from the screening of the NDM-1 in lake water samples polluted from untreated sewage and industrial effluents from manufacturing plants exhibited a more significant impact with a higher copy number representing their prevalence rate to be significantly higher. The study renders the grueling scenario concerning increased exploitation of surface water resources for industrial and urban requirements, resulting in the degradation of water quality, which indirectly affects the floral and faunal eco-systems with blooming hazardous chemical constituents disposed of untreated.

\section{Conclusion}

The study demonstrated a high precision of a real-time qPCR analysis for detecting the NDM-1 gene in the water compartment of lakes. The NDM-1 gene was detected in all water samples collected from 17 different sampling locations. The highest value of the NDM-1 gene copies number was observed in the Mir Alam tank (985.74), followed by the Himayat Sagar lake (607.22) and the 
Manjeera dam (417.37). These water bodies were contaminated due to the combined discharge of domestic sewage and industrial effluents. Results showed that the abundance of NDM-1 in these water bodies poses a severe threat to public health. This transferable ARG proliferation among diseasecausing bacteria led to the emergence of multi-drug resistant genes resistant in all current-generation antibiotics. The study concluded that the persistent occurrence of the NDM-1 gene disseminated in an aquatic environment poses a more significant threat leading to increased pathogenicity and ARG transferability among microbiomes that have remained unperturbed before the intrusion of antimicrobial agents.

Additionally, due to abusive utilization under domestic consumption in urban wastewater discharges also observed an alarming degree of NDM-1 prevalence. As a result, exposure to antibiotics enriched concentrations distributed the microbial communities within the aquatic environment to attain an anthropogenic effect, thus creating health-related complications with multiple resistance against antibiotics. Thus, the study indirectly represented inadequate wastewater management from drug manufacturing plants and sewage treatment plants, resulting in a sudden increase in the antibiotic concentration in water resources, which in particular appeared to be of direct dissemination of NDM-1 producing pathogens. The global phenomenon about the spread of NDM-1 presents a significant challenge to tackle such a daunting issue with framing a sustainable approach, enforcing firm regulations and directions for waste disposal for pharmaceutical producers and regulatory agencies.

\section{Strength and limitations}

The quality of the present analysis is the wide variation of sampling locations, precise documentation of sampling locations, and usage of highly sophisticated real-time qPCR techniques. There is the presence of billions of bacteria in each water sample. Since qPCR was employed to demonstrate the abundance of the NDM-1 in collected water samples, a positive outcome for almost all genes in any sample comprising sewage or faecal matter is anticipated.

\section{Acknowledgements}

The authors thank the University Grant Commission (UGC), New Delhi for providing financial assistance, and IIT Hyderabad for providing lab facilities for the smooth conduct of this work.

\section{Declaration of Interest Statement}

There are no known conflicts of interest associated with this publication and no significant financial support for this work that could have influenced its outcome.

\section{References}

[1] Vikesland, P. J., Pruden, A., Alvarez, P. J., Aga, D., Bürgmann, H., Li, X. D. \& Zhu, Y. G. (2017). Toward a comprehensive strategy to mitigate dissemination of environmental sources of antibiotic resistance. Environ Sci Technol., 51(22):13061-13069. doi: 10.1021/acs.est.7b03623.

[2] Totsika, M. (2016). Benefits and challenges of antivirulence antimicrobials at the dawn of the postantibiotic era. Drug Delivery Letters, 6(1), 30-37. doi:10.2174/2210303106666160506120057

[3] Ferri, M., Ranucci, E., Romagnoli, P., \& Giaccone, V. (2017). Antimicrobial resistance: a global emerging threat to public health systems. Critical Reviews in Food Science and Nutrition, 57(13), 2857-2876. doi: 10.1080/10408398.2015.1077192.

[4] Streit, W. R., \& Daniel, R. (2017). Metagenomics. Springer New York. 
[5] Wilke, M. H. (2010). Multi-resistant bacteria and current therapy-the economical side of the story. European Journal of Medical Research, 15(12), 571. doi: 10.1186/2047-783X-15-12-571.

[6] Garner, E. D. (2018). Occurrence and Control of Microbial Contaminants of Emerging Concern through the Urban Water Cycle: Molecular Profiling of Opportunistic Pathogens and Antibiotic Resistance (Doctoral dissertation, Virginia Tech). URL: http://hdl.handle.net/10919/93743

[7] Picao, RC, Cardoso, JP, Campana, EH, Nicoletti AG, Petrolini, FVB, Assis, DM, Juliano, L., Gales, AC. (2013). The route of antimicrobial resistance from the hospital effluent to the environment: focus on the occurrence of KPC-producing Aeromonas spp. and Enterobacteriaceae in sewage. Diagn Microbiol Infect Dis 76(1):80-85. doi: 10.1016/j.diagmicrobio.2013.02.001.

[8] Blaak A, Lynch G, Italiaander R, Hamidjaja RA, Schets FM, de Roda Husman AM (2015). Multidrugresistant and extended spectrum beta-lactamase producing escherichia coli in dutch surface water and wastewater. PLoS One 10:6-15. doi: 10.1371/journal.pone.0127752.

[9] Adegoke AA, Stentor TA, Okoh AI (2017). Stenotrophomonas maltophilia as an emerging ubiquitous pathogen: looking beyond contemporary antibiotic therapy. Front Microbiol 8:2276. doi: 10.3389/fmicb.2017.02276.

[10] Li, L. G., Xia, Y., \& Zhang, T. (2017). Co-occurrence of antibiotic and metal resistance genes revealed in complete genome collection. The ISME Journal, 11(3), 651-662. doi: 10.1038/ismej.2016.155.

[11] Tehrani, A. H., \& Gilbride, K. A. (2018). A closer look at the antibiotic-resistant bacterial community found in urban wastewater treatment systems. Microbiology Open, 7(4), e00589. doi: 10.1002/mbo3.589.

[12] Holmes, A. H., Moore, L. S., Sundsfjord, A., Steinbakk, M., Regmi, S., Karkey, A., Gurein, PJ., Piddock, LJV. (2016). Understanding the mechanisms and drivers of antimicrobial resistance. The Lancet Infectious Diseases, 387(10014), 176-187. doi: 10.1016/S0140-6736(15)00473-0.

[13] Marathe, N. P., Pal, C., Gaikwad, S. S., Jonsson, V., Kristiansson, E., Larsson, DGJ. (2017). Untreated urban waste contaminates Indian river sediments with resistance genes to last resort antibiotics. Water Research, 124, 388-397. doi: 10.1016/j.watres.2017.07.060.

[14] Kumarasamy, K. K., Toleman, M. A., Walsh, T. R., Bagaria, J., Butt, F., Balakrishnan, R., Woodford, N. (2010). Emergence of a new antibiotic resistance mechanism in India, Pakistan, and the UK: A molecular, biological, and epidemiological study. The Lancet Infectious Diseases, 10(9), 597-602. doi: 10.1016/S1473-3099(10)70143-2.

[15] Lübbert, C., Baars, C., Dayakar, A., Lippmann, N., Rodloff, A. C., Kinzig, M., \& Sörgel, F. (2017). Environmental pollution with antimicrobial agents from bulk drug manufacturing industries in Hyderabad, South India, is associated with dissemination of extended-spectrum beta-lactamase and carbapenemaseproducing pathogens. Infection, 45(4), 479-491. doi: 10.1007/s15010-017-1007-2.

[16] Fick J, Söderström H, Lindberg RH, Phan, C., Tysklind, M., Larsson, DGJ. (2009). Contamination of surface, ground, and drinking water from pharmaceutical production. Environ Toxicol Chem., 28(12):25227. doi: 10.1897/09-073.1.

[17] Rutgersson C, Fick J, Marathe N, Kristiansson, E., Janzon, A., Angelin, M., Johansson, A., Shouche, Y., Flach, C-F., Larsson, DGJ. (2014). Fluoroquinolones and qnr genes in sediment, water, soil, and human fecal flora in an environment polluted by manufacturing discharges. Environ Sci Technol., 48 (14):782532. doi: 10.1021/es501452a.

[18] Walsh, T R., Weeks, J., Livermore, D. M., Toleman, M. A. (2011). Dissemination of NDM-1 positive bacteria in the New Delhi environment and its implications for human health: An environmental point prevalence study. The Lancet Infectious Diseases, 11(5), 355-362. doi: 10.1016/S1473-3099(11)70059-7.

[19] Rathinasabapathi, P, Hiremath, DS, Arunraj, R and Parani, M. (2015). Molecular Detection of New Delhi Metallo-Beta-Lactamase-1 (NDM-1) Positive Bacteria from Environmental and Drinking Water Samples

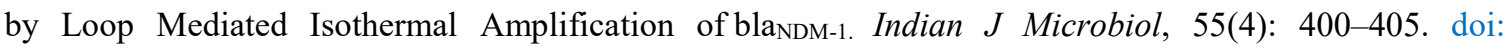
10.1007/s12088-015-0540-x. 
[20] Struelens MJ, Monnet DL, Magiorakos AP, Santos O’Connor F, Giesecke J., European NDM-1 Survey Participants. (2010). The New Delhi metallo-beta-lactamase 1-producing Enterobacteriaceae: emergence and response in Europe. Euro Surveill 15(46):19716. doi: 10.2807/ese.15.46.19716-en.

[21] Kumarasamy KK, Toleman MA, Walsh TR, et al. (2010). The emergence of a new antibiotic resistance mechanism in India, Pakistan, and the UK: a molecular, biological, and epidemiological study. Lancet Infect Dis. 10: 597-602. doi:10.1016/S1473-3099(10)70143-2.

[22] Deshpande P, Rodrigues C, Shetty A, Kapadia F, Hedge A, Soman R. (2010). New Delhi Metallo-beta lactamase (NDM-1) in Enterobacteriaceae: treatment options with carbapenems compromised. $J$ Assoc Physicians India. 58: 147-49. PMID: 20848811

[23] Livermore DM, Walsh TR, Toleman M, Woodford N. (2010). BalkanNDM-1: escape or transplant? Lancet Infect Dis. 11: 164. doi:10.1016/S1473-3099(10)70202-X.

[24] Jamwal P, Mittal AK, Mouchel JM. (2009). Efficiency evaluation of sewage treatment plants with different technologies in Delhi (India). Environ Monit Assess. 153: 293-305. doi: 10.1007/s10661-008-0356-9.

[25] Chen Y, Su J-Q., Zhang J., Chen, H., Zhang, B., Gin KY., He, Y. (2019). High-throughput profiling of antibiotic resistance gene dynamic in a drinking water river-reservoir system. Water Research 149, 179189. doi: 10.1016/j.watres.2018.11.007

[26] Eramo, A.; Medina, W. R. M.; Fahrenfeld, N. L. (2020). Factors associated with elevated levels of antibiotic resistance genes in sewer sediments and wastewater. Environ. Sci.: Water Res. Technol., 6, 1697-1710. doi: 10.1039/D0EW00230E

[27] Bora A, Ahmed GU, Hazarika NK, Prasad KN, Shukla SK, Randhawa V., Sarma, JB. (2013). Incidence of blaNDM-1 gene in Escherichia coli isolates at a tertiary care referral hospital in Northeast India. Indian Journal of Medical Microbiology, 31(3): 250-256. doi:10.4103/0255-0857.115628

[28] Deshpande P, Rodrigues C, Shetty A, Kapadia F, Hedge A, Soman R. (2010). New Delhi Metallo-beta lactamase (NDM-1) in Enterobacteriaceae: Treatment options with carbapenems compromised. J Assoc Physicians India, 58:147-9. PMID: 20848811.

[29] Jamal WY, Albert MJ, Rotimi VO (2016). High Prevalence of New Delhi Metallo- $\beta$ Lactamase-1 (NDM-1) Producers among Carbapenem-Resistant Enterobacteriaceae in Kuwait. PloS one, 31:11(3): e0152638. doi: 10.1371/journal.pone.0152638.

[30] Katouli M, Thompson JM, Gundogdu A, Stratton H.M. (2012). Antibiotic Resistant Bacteria in Hospital Wastewaters and Sewage Treatment Plants. In: Science Forum and Stakeholder Engagement: Building Linkages, Collaboration and Science Quality, 225-229.

[31] Alam MZ, Aqil F, Ahmad I, Ahmad S. (2013). Incidence and transferability of antibiotic resistance in the enteric bacteria isolated from hospital wastewater. Braz J Microbiol., 44(3):799-806. doi: 10.1590/s151783822013000300021

[32] Devarajan N, Laffite A, Mulaji CK, Otamonga JP, Mpiana PT, Mubedi JL, Prabakar K, Ibelings BW, Pote J. (2016). Occurrence of Antibiotic Resistance Genes and Bacterial Markers in a Tropical River Receiving Hospital and Urban Wastewaters. PloS one., 11(2): e0149211. doi:10.1371/journal.pone.0149211.

[33] D'costa VM, King CE, Kalan L, Morar M, Sung WWL, Schwarz C., Froese, D., Zazula, G., Calmels, F., Debryune, R., Golding, GB., Poinar, HN., Wright, GD. (2011). Antibiotic resistance is ancient. Nature, 477 (7365):457-461. doi: 10.1038/nature10388.

[34] Gayathri D, Eramma NK, Devaraja TN. (2012). New Delhi metallo beta- Lactamase1: Incidence and threats. Int J Biol Med Res., 3(2): 1870-1874. ISSN: 0976:6685

[35] Carattoli A, Villa L, Poirel L, Bonnin RA, Nordmann P. (2012). Evolution of IncA/C bla CMY-2-carrying plasmids by acquisition of the blaNDM-1 carbapenemase gene. Antimicrob Agents Chemother., 56 (2):783-786. doi: 10.1128/AAC.05116-11.

[36] Rafei R, Dabboussi F, Hamze M, Eveillard M, Lemarie C, Mallat H., Rolain J-M., Joly-Guillou, M-L., Kempf, M. (2014). First report of blaNDM-1-producing Acinetobacter baumannii isolated in Lebanon from civilians wounded during the Syrian war. Int J Infect Dis., 21:21-23. doi: 10.1016/j.ijid.2014.01.004. 
[37] Liu C, Qin S, Xu H, Xu L, Zhao D, Liu X., Lang, S., Feng, X., Liu, H-M. (2015). New Delhi Metallo- $\beta$ Lactamase 1(NDM-1), the Dominant Carbapenemase Detected in Carbapenem-Resistant Enterobacter cloacae from Henan Province, China. PloS one., 10(8): e0135044. doi: 10.1371/journal.pone.0135044

[38] Zhang, C., Qiu, S., Wang, Y., Qi, L., Hao, R., Liu, X., ... \& Song, H. (2013). Higher isolation of NDM-1 producing Acinetobacter baumannii from the sewage of the hospitals in Beijing. PloS one, 8(6), e64857. doi: 10.1371/journal.pone.0064857

[39] Chandran SP, Diwan V, Tamhankar AJ, Joseph BV, Rosales-Klintz S, Mundayoor S, Lundborg CS, Macaden R. (2014). Detection of carbapenem resistance genes and cephalosporin, and quinolone resistance genes along with oqxAB gene in Escherichia coli in hospital wastewater: a matter of concern. $J$ Appl Microbiol.,117(4):984-995. doi: 10.1111/jam.12591.

[40] Isozumi, R., Yoshimatsu, K., Yamashiro, T., Hasebe, F., Nguyen, BM., Ngo, TC., Yasuda, SP., Koma, T., Shimuzu, K., Arikawa, J. (2012). bla(NDM-1)-positive Klebsiella pneumoniae from environment, Vietnam. Emerges Infect Dis., 18(8):1383-1385. doi: 10.3201/eid1808.111816.

[41] Foxman B. (2014). Urinary tract infection syndromes: occurrence, recurrence, bacteriology, risk factors, and disease burden. Infect Dis Clin North Am., 28 (1): 1-13. doi: 10.1016/j.idc.2013.09.003.

[42] Yong D, Toleman MA, Giske CG, Cho HS, Sundman K, Lee K., Walsh, TR. (2009). Characterization of a new metallo- $\beta$-lactamase gene, blaNDM-1 and a novel erythromycin esterase gene carried on a unique genetic structure in Klebsiella pneumoniae sequence type 14 from India. Antimicrob Agents Chemother., 53 (12):5046-5054. doi: 10.1128/AAC.00774-09. 